\title{
Steam Locomotives: a forgotten era
}

\section{AOII J.A. Hattingh*}

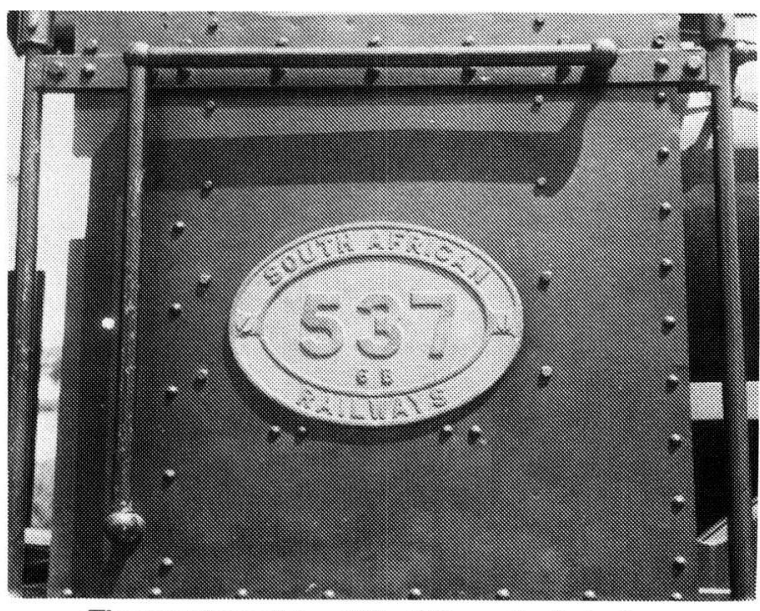

The number-plate of No 498 as she is today

Steam built the Republic as we know it but unfortunately it is on its way out. These graceful Old Ladies are being cut up and at this stage there are approximately seven hundred locomotives still operating in the Republic of South Africa. Fortunately there are a number of Preservation Societies throughout the country that are trying to preserve a forgotten era.

The reason for this article is firstly to draw attention to the historical aspect of the Old Locomotives and the role that they played and to the casual questions that are asked by the visitors to Fort Klapperkop Museum.

I trust that this article will answer some of them and will generate a sense of pride in some of the inventions that our forefathers developed.

As far as can be ascertained all requests for an old locomotive had been verbal between the Military Museum and that of the then South African Railways now the South African Transport Services.

Mr Coffee then started the ball rolling and on the 17 November 1971, the then Minister of Transport, the late Mr Ben Schoeman, gave the necessary permission for the engine, Class $6 \mathrm{~B}$, No 498 and coal tender No 633 to be donated to the Military Museum at Fort Klapperkop.

It should be noted that this locomotive now bears the number of 537. This is in fact incorrect. The reason being that the number plates had been removed from 498 and was in fact scrap- ped and ready to be cut up. She had been moved up to the Locomotive Yards in Germiston.

The request for the old locomotive came in time for the Old Girl and the reason: She was the only Class 6 in the area and therefore she would be saved.

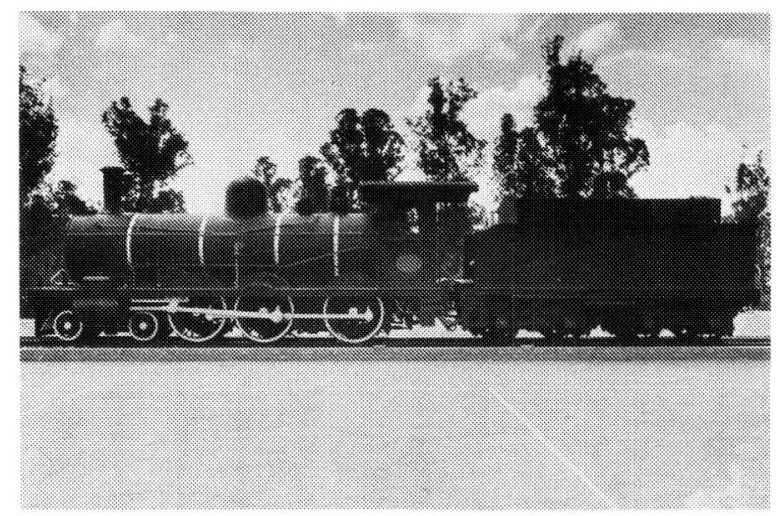

Class 6B locomotive No 537 at Fort Klapperkop museum

The only number plates that could be found were those of number 537 and therefore they were attached to the locomotive.

Number 498 was built in Great Britain by Neilson, Reid and Co. She was one of an order of fifty four locomotives and delivered to the Central Government Railways (CGR) where she operated under the number of 210 . Her makers number was 5131 . She now has the coal tender of 633XD. The tender was built in 1901.

The cost at the time of purchase was:

Engine: $£ 3000,9 d(R 6000,18)$

Tender: £ 781,00 (R1562,00)

This locomotive is a plate frame locomotive and is practically identical to that of the Class $6 \mathrm{~A}$. One of the main differences is that the coal tender has an eight wheeled tender where that of the Class $6 \mathrm{~A}$ has a six wheel.

This locomotive was originally designed by the locomotive superintendent, Michael Stephens. The main reason for it's design was a fast passenger service on the Central Government Railways. 
Number 498 is fitted with a Stephenson valve gear and the engine's working weight was 46 tons $5 \mathrm{cwt}$ and that of the tender 34 tons $2 \mathrm{cwt}$ and had a tractive force of 16690 pounds at $75 \%$ and the size of the cylinders was seventeen inches and the length of the stroke was twenty six inches.

The size of the wheels was four foot six inches diameter and were coupled. The size of the leading bogie wheels was two foot four and a half inches. Her working pressure was 180 pounds per square inch. Her overall length over the couplers was 53 feet nine and three quarter inches. Her coal capacity was $5 \frac{1}{2}$ tons and the water capacity was that of 2600 gallons. Her total heating capacity was 1160 square feet and her fire grate area was 16625 square feet.

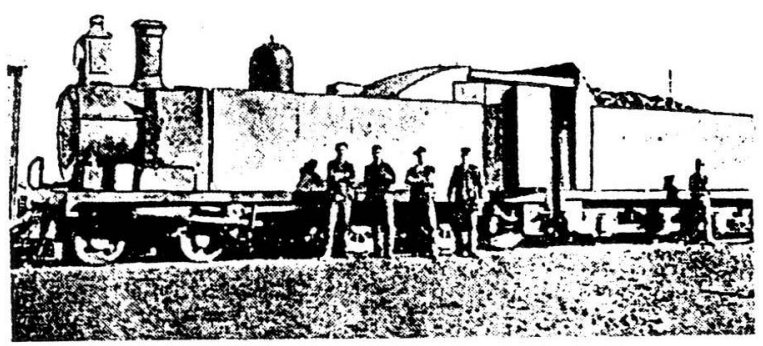

An old armoured locomotive showing the plating in position

In 1894 the then General Manager, Mr Elliott made reference to the Class 6 locomotive in his report. "These engines will render practicable as increase in speed that will admit of a train being run from Cape Town to Johannesburg within 48 hours. Between Cape Town and Worcester they have practically done away with the necessity of attaching assisting engines to passenger trains and easily haul a goods train consisting of 35 loaded vehicles from Cape Town to Worcester and an up cattle train of 40 vehicles." (Extract from the Locomotive in South Africa by E. Espitalier and W. Day.)

A number of locomotives were sold to the Benguella Railways and consisted of the following locomotives: Locomotive No 185, a Class 6A, sold in 1907. She was built in 1897 by Dubs and Company and her makers number was 3446 .

Locomotives no 218 and no 223 were sold in 1907 and 1908 respectively. Both locomotives were built by Nelson and Company in 1898 and had makers numbers of 5139 and 5144 .
In 1910 locomotive No 588 was sold and the makers number was 5274 , built in 1898 by Nelson, Reid and Company. The last of the Class $6 \mathrm{~B}$ locomotives that were sold to the Benguella Railways was No 600 and the makers number was 5324.

During World War II sixteen 6th class locomotives were sold to the Sudan Government Railways in 1942 and consisted of No 402, 403, 406, $417,421,423,436$ of the Class 6 . Numbers: 465 , 472,475 and 479 in the Class $6 \mathrm{~A}$ and $6 \mathrm{~B}$ were locomotives No 534, and 538 and in the $6 \mathrm{C}$ Class, No 548 and the 6D No 572 and 687.

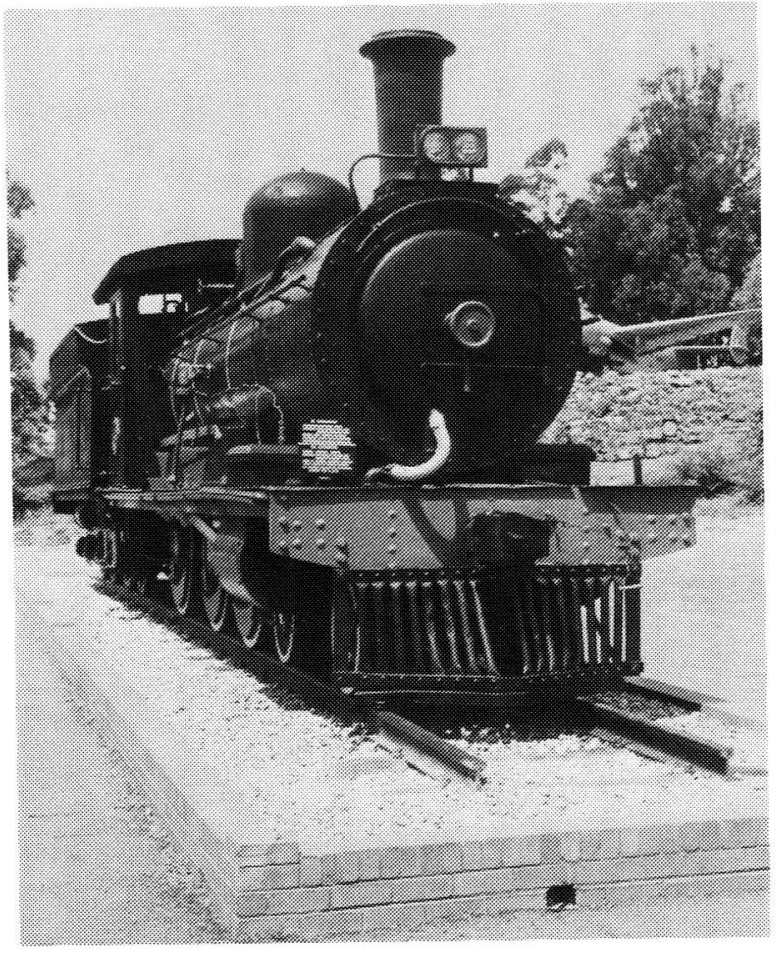

Historic plaque mounted on the locomotive

It was found that all of the Class 6 locomotives were generally fast, good steamers, and were easy handlers. Maintenance was low and they could operate for long periods between overhauls. Although placed in service with the CGR they saw active service in practically the whole country except Natal, where they were used for all types of traffic. They were placed on suburban lines until they were replaced by electric units and then they were delegated to the shunting yards.

On the 7th October 1899 the operations of the CGR was suspended and placed in the hands of the armed forces. The name then became the Imperial Military Railways, (IMR) under the 
directorship of Lieut-Col E.G.C. Girouard KCMC; DSO; RE. He left the running of the CGR as it was and took control of the Natal Government Railways and as the war progressed that of the Free State and Transvaal. The workshops in the captured areas of Bloemfontein and later Pretoria were reasonably well equipped. These workshops did a great deal of work and some unusual tasks, for instance the mounting of guns and the armouring of trains.

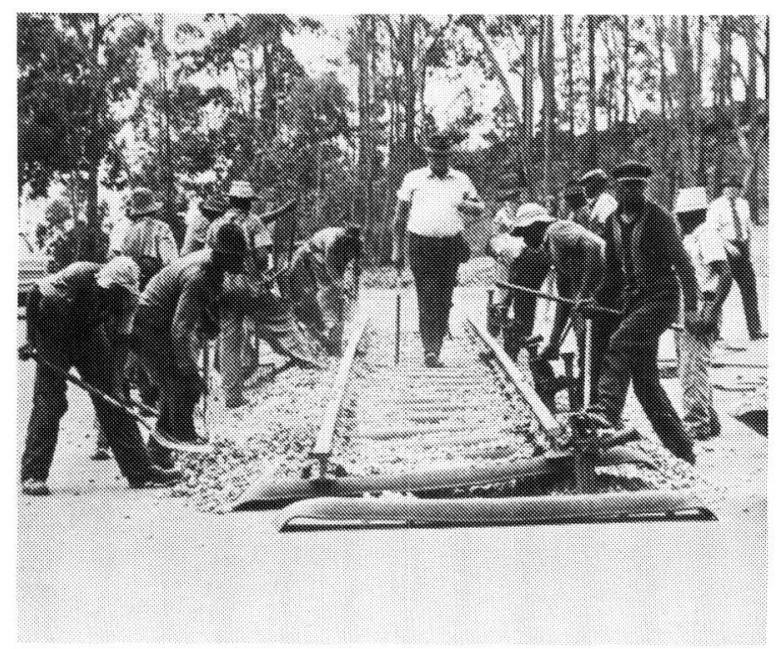

The construction of the Track

It was found that between October 1900 and September 1901 approximately 223 locomotives had been repaired and placed in service again in the Free State and Transvaal.

Several armoured trains were built and equipped during this time. There were a couple of Class 03, 05 and the 6th and 7th Class locomotives. Included in this list was the captured 46 ton type locomotive of the NZASM.

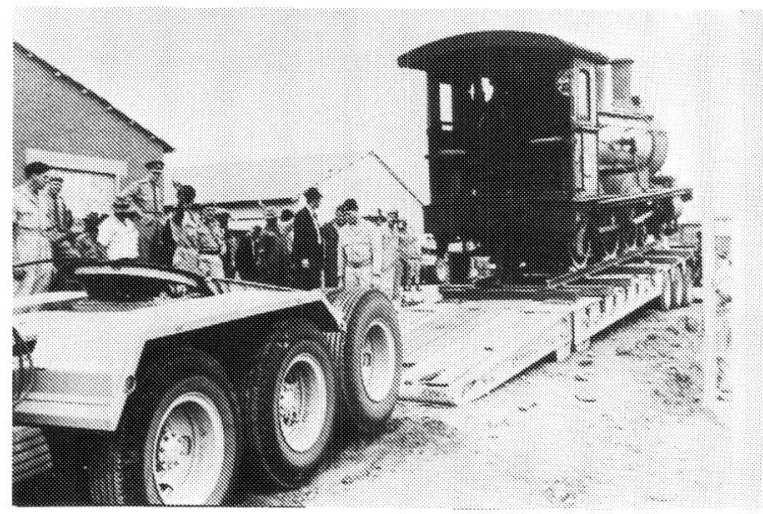

The "Old Girl" at swing 81 Verwoerdburg

Armouring took the form of the following: The $\mathrm{cab}$, the tender and injector pipes were protected with steel plates. To protect the crew from fire from the rear, a curved steel hood was attached to the cab roof and extended down over the front end of the tender. From the side of the cab, small slide wing plates projected, into which the driver could put his head and could get a view of the rear and the front of the engine through spy holes.

Openings were provided on each side of the locomotive and could be closed by a sliding steel door or plate. The boiler was not armoured as the idea was that it was bullet proof.

The locomotives were arranged into groups of five and for each group there was an engine as standby.

As far as can be ascertained, locomotive No 537 was never armoured, but did work draw trains and freight trains during the Anglo-Boer War too and from Pretoria. It can be assumed that in her near retirement time that she was placed on a suburban line. She was sent to East London where she continued until being withdrawn from service on the 17th June 1970 due to "Worn out beyond economical repair."

She was re-boilered in 1926 and the boiler No 1407 was commissioned. The old boiler was cut up.

When the necessary authority had been granted No 537 was steamed up and she made her own way to Verwoerdburg No 81 siding where the last trip was about to begin. She was placed on a low bed vehicle and then transported to the museum by road. The tracks had already been laid and awaited the Grand Old Lady. She now faces South from whence She came.

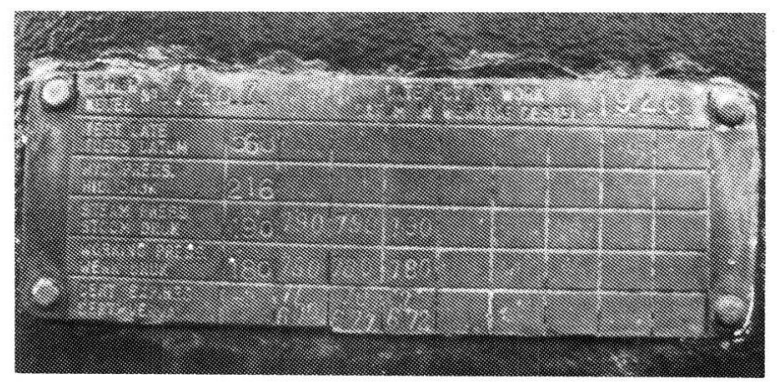

Boiler plate

As to the fate of engine 537 all that can be assumed, was that she suffered a fate from which 498 was saved, only there was no one to save her, and more than likely she was cut up. 
No 537's old number on the CGR was 598 and at the Union when all the locomotives were renumbered she received the number 537 . As to her work and where she spent her last years there is not much known, but it can be assumed that she had an honourable and hard working life and was more than likely also withdrawn from service due to "worn out beyond economical repairs."

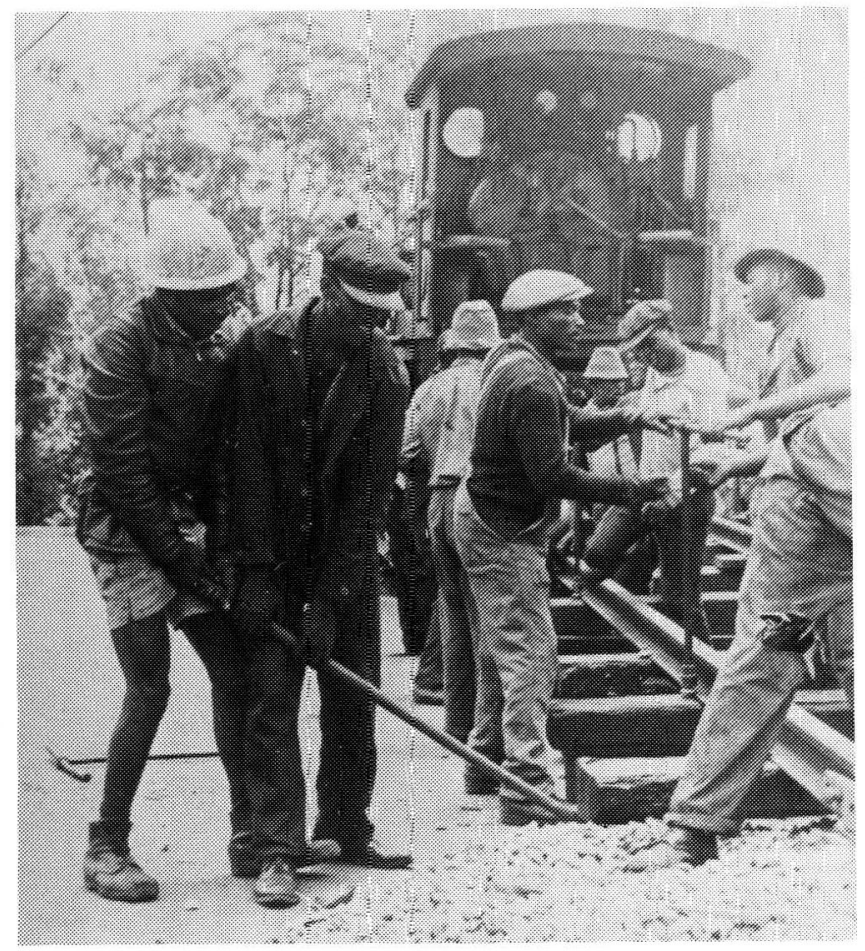

Loose track in place for the unloading onto her final resting place
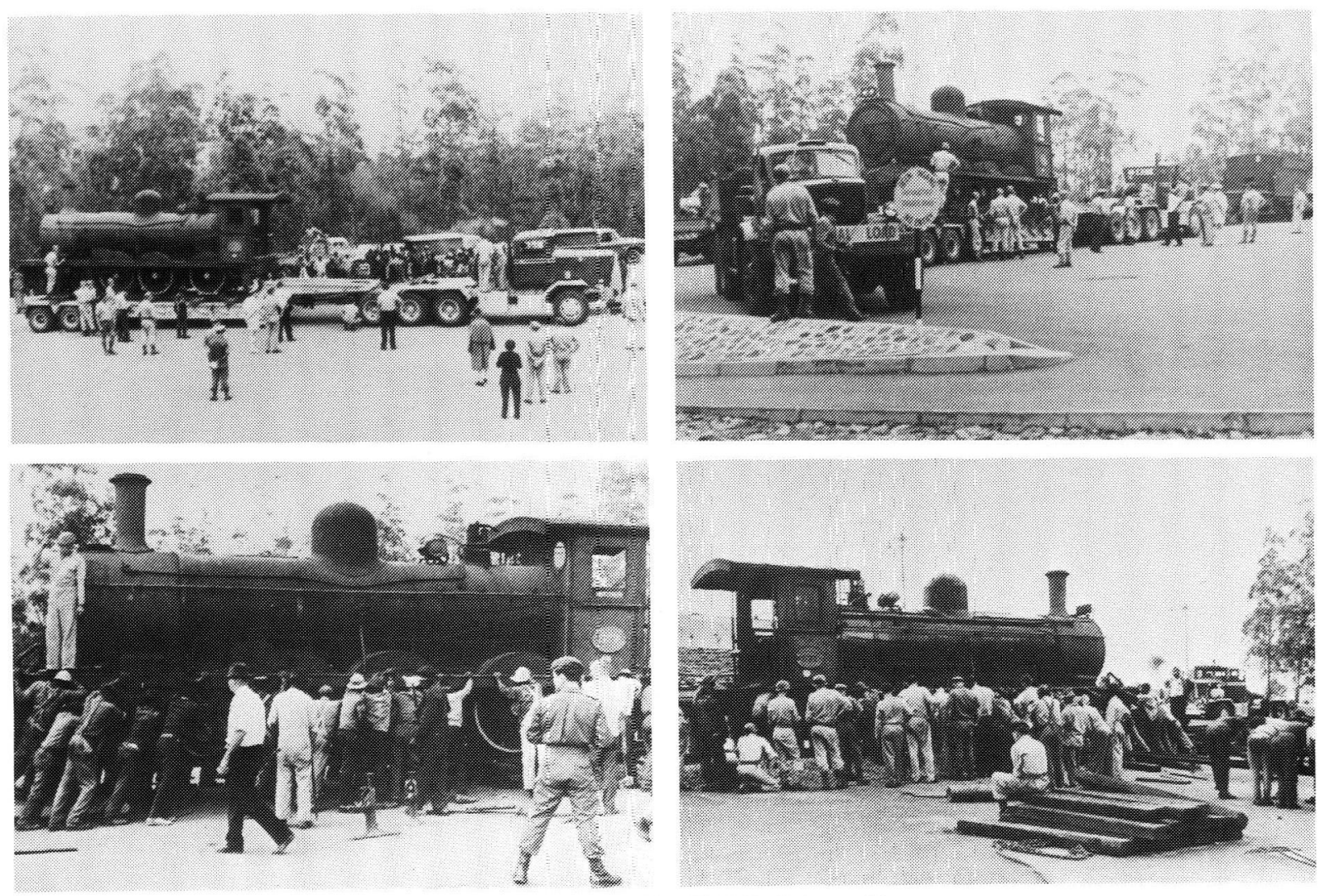

Manpower to move the "Old Girl" in position 
*AOII J.A. Hattingh, Diploma (Printers), attested in the SADF on 1 February 1978 and is employed as a photolithographer.

\section{Reference Material}

1. The Locomotive in South Africa, T.C. Espitalier and W. Day.

2. A concise guide to locomotives of the South African Railways by $L$. Paxton and D. Bourne.
3. Locomotives of the South African Railways volumes I and II by D. Holland.

A special word of thanks should be given to Mr Pivnic at the SATS Museum for all the documents that have been included in the article and to the Military Museum for the photographs of the unloading and track construction. 